\title{
Elevated temperature treatment as a novel method for decreasing p57 on the cell surface of Renibacterium salmoninarum
}

\author{
Jon D. Piganelli ${ }^{* * *}$, Gregory D. Wiens ${ }^{* * * *}$, Stephen L. Kaattari**** \\ Department of Microbiology and Center for Salmon Disease Research, Oregon State University, Corvallis, Oregon 97331, USA
}

\begin{abstract}
Renibacterium salmoninarum is a Gram-positive diplo-bacillus and the causative agent of bacterial kidney disease, a prevalent disease of salmonid fish. Virulent isolates of $R$. salmoninarum have a hydrophobic cell surface and express the 57-58 kDa protein (p57). Here we have investigated parameters which effect cell hydrophobicity and p57 degradation. Incubation of $R$. salmoninarum cells at $37^{\circ} \mathrm{C}$ for $>4 \mathrm{~h}$ decreased cell surface hydrophobicity as measured by the salt aggregation assay, and decreased the amount of cell associated p57. Incubation of cells at lower temperatures $(22,17,4$ or $-20^{\circ} \mathrm{C}$ ) for up to $16 \mathrm{~h}$ did not reduce hydrophobicity or the amount of cell associated $\mathrm{p} 57$. Both the loss of cell surface hydrophobicity and the degradation of 057 were inhibited by pre-incubation with the serine protease inhibitor phenylmethylsulfonyl fluoride (PMSF). Cell surface hydrophobicity was specifically reconstituted by incubation with extracellular protein (ECP) concentrated from culture supernatant and was correlated with the reassociation of p57 onto the bacterial cell surface as determined by western blot and total protein stain analyses. The ability of $\mathrm{p} 57$ to reassociate suggests that the bacterial cell surface is not irreversibly modified by the $37^{\circ} \mathrm{C}$ treatment and that p5 contributes to the hydrophobic nature of $R$. salmoninarum. In summary, we describe parameters effecting the removal of the p57 virulence factor and suggest the utility of this modification for generating a whole cell vaccine against bacterial kidney disease.
\end{abstract}

KEY WORDS: Renibacterium salmoninarum - Bacterial kidney disease $\cdot$ p57

\section{INTRODUCTION}

Bacterial kidney disease (BKD) is a chronic and systemic disease that is often fatal for salmonids (Fryer \& Sanders 1981). The causative agent, Renibacterium salmoninarum is a Gram-positive, non-motile, slow

-J. Piganelli and G. Wiens contributed equally to this manuscript.

Present addresses:

- Barbara Davis Center for Childhood Diabetes and Department of Immunology, University of Colorado Health Sciences Center, Denver, Colorado 80262, USA. E-mail: jon.piganelli@uchsc.edu

-.Department of Molecular Microbiology and Immunology, Oregon Health Sciences University, Portland, Oregon 97219, USA

-...School of Marine Science, Virginia Institute of Marine Science, The College of William \& Mary, Gloucester Point, Virginia 23062, USA. growing, fastidious, pathogen (Fryer \& Sanders 1981 , Bruno 1986, Evenden et al. 1993). BKD is considered one of the most difficult salmonid bacterial diseases to control (Elliott et al. 1989) and many aspects of the pathogenesis and causative agent are still poorly understood. $R$. salmoninarum is a facultative intracellular parasite that has the ability to survive and possibly multiply within phagocytic cells (Bruno 1986, Austin \& Austin 1987, Bandin 1993, Gutenberger et al. 1997). The chronic course of disease and intracellular residence suggests that the organism may exploit a variety of pathogenic mechanisms causing the physiological and pathological changes associated with BKD. Research on the pathogenic mechanisms and the development of a vaccine have been hampered by the lengthy incubation times required for primary culture and experimental challenge of fish ( 1 to $4 \mathrm{mo}$ ) (Fryer \& Sanders 1981, Toranzo \& Barja 1993). 
A characteristic of virulent Renibacterium salmoninarum isolates is the tendency of bacterial cells to autoaggregate due to a hydrophobic cell surface (Daly \& Stevenson 1987, Bruno 1988). Subsequent work suggested that less virulent isolates lack the saline extractable $57 \mathrm{kDa}$ protein (Bruno 1990) also referred to as p57 (Wiens \& Kaattari 1991). Previously we have found that $R$. salmoninarum produces large amounts of p57 during in vitro culture and in vivo infection (Turaga et al. 1987a, Wiens \& Kaattari 1989, Rockey et al. 1991a). P57, in addition to being a secreted protein, is also a predominant cell surface component present on most isolates of $R$. salmoninarum (Getchell et al, 1985, Wiens \& Kaattari 1989, Daly \& Stevenson 1990, Bandin et al. 1992). A number of in vitro functions have been attributed to $\mathrm{p} 57$ and to the extracellular proteins (ECP) harvested from bacterial culture supernatant. We and others have previously demonstrated that incubation of ECP or p57 with salmonid lymphocytes causes in vitro immunosuppression of antibody production to non-related antigens TNP-LPS or human gammaglobulin (Turaga et al. 1987b, Rockey et al. 1991b, Fredriksen et al. 1997). In addition, ECP agglutinates salmonid leukocytes, and this activity can be blocked by preincubation with monoclonal antibodies that recognize the amino-terminal portion of p57 (Wiens \& Kaattari 1991). P57 can also agglutinate rabbit and other mammalian erythrocytes (Daly \& Stevenson 1987, 1990). These data support the hypothesis that p57 in ECP has biological activity that may be linked to virulence.

In addition to $\mathrm{p} 57, \mathrm{ECP}$ contains proteolytic activity that is especially active at elevated temperatures (Rockey et al. 1991b), contributing to the instability and degradation of p57 (Griffiths \& Lynch 1991). Incubation of ECP at $37^{\circ} \mathrm{C}$ removes the majority of proteins present in ECP, including p57, as determined by SDS-PAGE and western blotting (Rockey et al. 1991b). The digestion of ECP also abrogates the immunosuppressive and leukoagglutinating activity of ECP (Rockey et al. 1991b, Wiens \& Kaattari 1991). The proteolytic activity is inhibited by phenylmethylsulfonyl fluoride (PMSF), and was therefore suggested to be a serine protease (Rockey et al. 1991b). Using substrate gel elctrophoresis, a band containing protease activity was identified with an approximate relative molecular mass of $100 \mathrm{kDa}$.

Recently, we reported that a $10 \mathrm{~h}$ incubation of Renibacterium salmoninarum cells at $37^{\circ} \mathrm{C}$ reduced cell surface associated p57- (Wood \& Kaattari 1996). Immunization of chinook salmon with the p57- cells produced a 20 -fold increase in antibody titers to periodate sensitive epitopes (Wood \& Kaattari 1996). Here we investigate the kinetics of p57 loss and alterations in cell surface hydrophobicity using the salt aggregation assay. We demonstrate that loss of cell surface p57 and hydrophobicity is inhibited by PMSF, suggesting that elevated temperature treatment effects serine protease activity. Cellular hydrophobicity and cell surface p57 were reconstituted by incubating $37^{\circ} \mathrm{C}$ treated bacterial cells in ECP, suggesting that the cell surface is not irreversibly modified by the $37^{\circ} \mathrm{C}$ temperature treatment. From these studies we determine conditions for producing $157^{-}$bacterial cells and, in a companion paper, suggest that cells devoid of this virulence factor may be an efficacious vaccine against BKD (Piganelli et al. 1998, in this issue).

\section{MATERIALS AND METHODS}

Preparation of bacterial cells and ECP. Renibacterium salmoninarum ATCC 33209 and isolate D6 (originally obtained from C. Banner, Oregon Department of Fish and Wildlife, Oregon State University, Corvallis, OR) were grown in $1 \mathrm{l}$ volumes in $2.5 \mathrm{llow}$ form, culture flasks (VWR) with continuous shaking at $17^{\circ} \mathrm{C}$. The KDM-II medium within which they were grown was prepared according to Evelyn (1977) except without serum supplementation. Bacteria were grown for 7 to $8 \mathrm{~d}$ to an absorbance between 0.4 and 1.0 (460 nm). Cells were pelleted at $6000 \times g$ centrifugation for $30 \mathrm{~min}$ and resuspended in $100 \mathrm{ml}$ cold phosphate buffered saline (PBS; $0.85 \% \mathrm{NaCl}, 10 \mathrm{mM} \mathrm{NaPO}_{4}, \mathrm{pH}$ 7.2). After a second centrifugation the cells were placed in microfuge tubes for the salt aggregation assay or stored at $-20^{\circ} \mathrm{C}$. ECP was extracted from culture supernatants as described by Wiens \& Kaattari (1989).

Salt aggregation assay. PBS washed Renibacterium salmoninarum cells were pelleted for $2 \mathrm{~min}$ at $14000 \mathrm{rpm}(18400 \times \mathrm{g})$ in a microfuge (Beckman, model E). The wet weight of the cells was determined after complete removal of supernatant. Cells were resuspended to a final concentration of $50 \mathrm{mg} \mathrm{ml}^{-1}$ in $10 \mathrm{mM}$ phosphate buffer without saline ( $\mathrm{pH} 7.2)$. These cells were then used in the salt aggregation assay according to the method of Lindahl et al. (1981) as described by Daly \& Stevenson (1987). Briefly, cells were diluted to yield an absorbance of $0.95(460 \mathrm{~nm})$ and $25 \mu$ of the cell suspension was mixed with $25 \mu$ l of 2 -fold dilutions of ammonium sulfate (from 2.0 to $0.004 \mathrm{M}$ ) in phosphate buffer that had been adjusted to $\mathrm{pH} 6.8$ with $1 \mathrm{~N}$ ammonium hydroxide. Mixtures were made in 12-well depression micro slides (Clay Adams, $N J$ ) that were then agitated for $5 \mathrm{~min}$ at $100 \mathrm{rpm}$ (Junior Orbit shaker. Labline Inc.). Aggregation was determined by observation of bacterial cell clumping with a dissecting scope (10x magnification) using oblique lighting. All assays were performed at room temperature. Hydrophobicity is inversely related to the concentration of ammonium sulfate required to effect aggregation. 
Effects of time and temperature treatments of Renibacterium salmoninarum cells. $R$. salmoninarum cells $\left(450 \mu \mathrm{l}\right.$ of $50 \mathrm{mg} \mathrm{ml}^{-1}$ cell suspension in $10 \mathrm{mM}$ phosphate buffer without salt) were incubated in microfuge tubes for $2,4,6,8$ or $16 \mathrm{~h}$ at either $-20,4,17,22$ or $37^{\circ} \mathrm{C}$. After incubation, cells were microfuged for $2 \mathrm{~min}$, and an aliquot of the cells and supernatant was retained for electrophoretic analysis.

Addition of protease inhibitors and antibiotics to Renibacterium salmoninarum cells. The protease inhibitor phenylmethlysulfonyl fluoride (Sigma) was added at concentrations of 2 to $15 \mathrm{mM}$ in $1 \%$ ethanol. A solution of $1 \%$ ethanol was also employed as a control. Antibiotics gentamycin, chloramphenicol, ampicillin, tetracycline or sodium azide were incubated with cells at a final concentration of $2.5 \mathrm{mg} \mathrm{ml}^{-1}$ at either 4 or $37^{\circ} \mathrm{C}$. After $8 \mathrm{~h}$ the cells were microfuged for 2 min and resuspended in PBS.

Addition of ECP and herterologous proteins to $37^{\circ} \mathrm{C}$ Renibacterium salmoninarum cells. $R$. salmoninarum cells were incubated at $37^{\circ} \mathrm{C}$ for $12 \mathrm{~h}$, washed in phosphate buffer without saline, and incubated with the following proteins: $4^{\circ} \mathrm{C}$ treated ECP, $37^{\circ} \mathrm{C}$ treated ECP, chicken ovalbumin, normal rainbow trout serum, or fetal bovine serum. All proteins were incubated with the $37^{\circ} \mathrm{C}$ treated $R$. salmoninaurm cells at $17^{\circ} \mathrm{C}$ for $1 \mathrm{~h}$, The cells were then microfuged, resuspended in phosphate buffer, and subjected to the salt aggregation assay.

Polyacrylamide gel electrophoresis and western blotting. Polyacrylamide gel electrophoresis and western blotting were performed as previously described (Wiens \& Kaattari 1989). Preparation of Renibacterium salmoninarum cells for electrophoresis was as described by Wiens \& Kaattari (1991).
Table 1. Renibacterium salmoninarum. Minimum molar concentration of ammonium sulfate $(M)$ required for detectable aggregation after incubation at the specified temperatures and times. Aggregation of cells was observed at $10 \times$ magnification

\begin{tabular}{|llllll|}
\hline Time (h) & \multicolumn{5}{c|}{ Temperature $\left({ }^{\circ} \mathrm{C}\right)$} \\
& \multicolumn{7}{c}{37} & 22 & 17 & 4 & -20 \\
\hline 0.5 & 0.004 & 0.004 & 0.004 & 0.004 & 0.004 \\
1.0 & 0.032 & 0.004 & 0.004 & 0.004 & 0.004 \\
1.5 & 0.25 & 0.004 & 0.004 & 0.004 & 0.004 \\
2.0 & 0.5 & 0.004 & 0.004 & 0.004 & 0.004 \\
4.0 & 2.0 & 0.004 & 0.004 & 0.004 & 0.004 \\
8.0 & 2.0 & 0.004 & 0.004 & 0.004 & 0.004 \\
16.0 & $>2.0$ & 0.004 & 0.004 & 0.004 & 0.004 \\
\hline
\end{tabular}

ation. Examination of cell associated proteins separated by electrophoresis through $10 \%$ SDS-polyacrylamide gels (Fig. 1A) demonstrated that incubation at $37^{\circ} \mathrm{C}$ decreased cell associated $\mathrm{p} 57$ but that this was not apparent in the 17,4 , or $-20^{\circ} \mathrm{C}$ treatments. Additional lower molecular weight proteins were observed to increase in concentration in $37^{\circ} \mathrm{C}$ treated cells consistent with degradation of p57 (Fig. 1A, lane 2). Some cell associated p57 appeared to remain after $16 \mathrm{~h}$ in agreement with our previous report that only $14 \%$ of the p57 molecule remains after a $10 \mathrm{~h}$ incubation at $37^{\circ} \mathrm{C}$ (Wood \& Kaattari 1996). Removal of p57 was essentially complete by $48 \mathrm{~h}$ (data not shown). Interest. ingly, analysis of the supernatants revealed that a large amount of protein was released (Fig. 1B, lane 2) from $37^{\circ} \mathrm{C}$ treated cells but not from cells incubated at lower temperatures of 17,4 or $-20^{\circ} \mathrm{C}$ (Fig. $1 \mathrm{~B}$, lanes 3-5). Addition of gentamycin, choloramphenicol, ampicillin, tetracycline, or sodium azide had no effect on the loss of hydrophobicity or protein degradation profiles at $37^{\circ} \mathrm{C}$, suggesting that protein synthesis or metabolism is not required (data not shown)

\section{RESULTS}

Elevated temperature decreased Renibacterium salmoninarum cell surface hydrophobicity and $\mathrm{p} 57$. Exposure of PBS washed $R$. salmoninarum cells to $37^{\circ} \mathrm{C}$ increased the concentration of ammonium sulfate required to cause aggregation from 0.004 to $2.0 \mathrm{M}$, indicating that the relative cell surface hydrophobicity was reduced by the elevated temperature incubation (Table 1). Loss of cell surface hydrophobicity appeared to be complete by 16 to $48 \mathrm{~h}$ (Table 1 and data not shown). Conversely, incubation of cells at $-20,4,17$ or $22^{\circ} \mathrm{C}$ for $16 \mathrm{~h}$ demonstrated no change in relative cell surface hydrophobicity, indicating that a temperature elevated above $22^{\circ} \mathrm{C}$ is critical for the cellular alter-
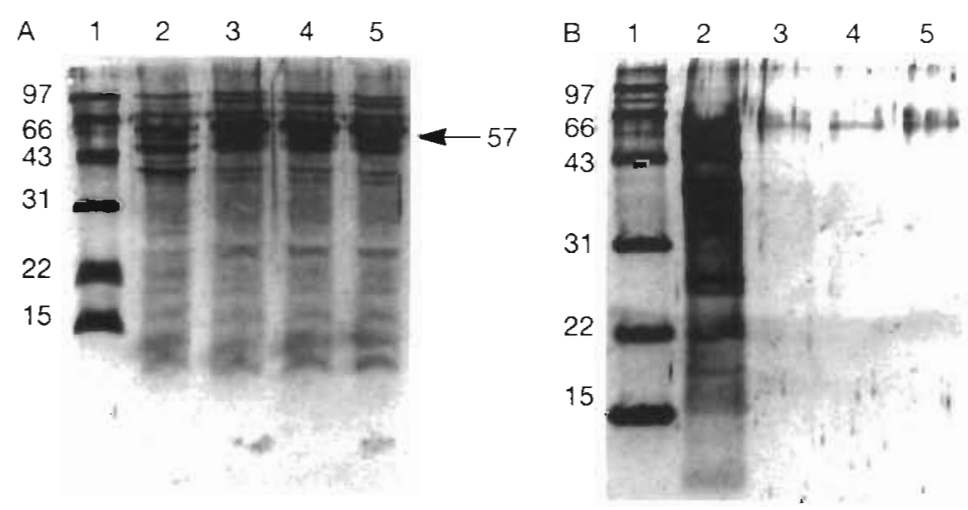

Fig. 1. Renibacterium salmoninarum. Total protein stains of (A) R. salmoninarum cells or (B) supernatants after incubation for $16 \mathrm{~h}$ at various temperatures. Lanes: molecular weight markers (1) and cells incubated at (2) $37^{\circ} \mathrm{C}$, (3) $17^{\circ} \mathrm{C},(4) 4^{\circ} \mathrm{C}$, and $(5)-20^{\circ} \mathrm{C}$ 
Table 2. Renibacterium salmoninarum. Minimum ammonium sulfate concentration required to produce aggregation of cells after incubation with concentrations of PMSF at $37^{\circ} \mathrm{C}$ for 12 h. +: aggregation, -: lack of aggregation of cells (10×magnification)

\begin{tabular}{|lccccc|}
\hline$\left(\mathrm{NH}_{4}\right)_{2} \mathrm{SO}_{4}(\mathrm{M})$ & \multicolumn{5}{c}{$\mathrm{PMSF}(\mathrm{mM})$} \\
& 0 & 2 & 5 & 10 & 15 \\
\hline 0.004 & - & - & - & + & + \\
0.032 & - & - & - & + & + \\
0.25 & - & - & + & + & + \\
0.5 & - & - & + & + & + \\
2.0 & + & + & + & + & + \\
\hline
\end{tabular}

Loss of Renibacterium salmoninarum cell surface hydrophobicity and p57 are prevented by incubation with the protease inhibitor PMSF. Incubation of $5 \mathrm{mM}$ PMSF partially blocked the temperature-induced reduction of cellular hydrophobicity, while concentrations greater than $10 \mathrm{mM}$ completely blocked loss of hydrophobicity (Table 2). These concentrations of PMSF were also able to block the degradation of cell associated p57 as determined by total protein stain and western blot (Fig. 2). Partial protection of p57 was observed using $2 \mathrm{mM}$ PMSF (Fig. 2A, lane 4) while complete protection of p57 was seen using 10 and $15 \mathrm{mM}$ PMSF (Fig 2A, lanes 6 and 7). The protection of p57 loss was more clearly observed by western blotting (Fig. 2B, lanes 5-8). Note that the $37^{\circ} \mathrm{C}$ treatment for $12 \mathrm{~h}$ removed all cell associated $4 \mathrm{D} 3$ immunoreactivity (Fig. 2B, lane 3). Interestingly, a small amount of higher molecular weight immunoreactive bands were more prevalent in preparations of cells containing PMSF, suggesting aggregation or multimerization of p57 in the presence of protease inhibitor. The presence of higher molecular weight forms of p57 was also enhanced by formalin treatment of bacterial cells (Fig. 3B, lane 3).

Relative cell surface hydrophobicity could be restored by the addition of $1.0 \mathrm{mg} \mathrm{ml}^{-1} \mathrm{ECP}$ to $37^{\circ} \mathrm{C}$ treated cells (Table 3 ). The restoration of hydrophobicity correlated with the reassociation of p57 with the bacterial cell surface as observed by total protein stain (Fig. 3A, lane 4) and the identity confirmed by western blot (Fig. 3B, lane 5). While p57 was the predominant component that was visualized by total protein stain, we do not exclude the possible contribution of other unidentified components present in ECP. These data suggest that the proteolytic activity did not irreversibly modify the cell surface, at least with respect to p57 reassociation. Treatment of ECP at $37^{\circ} \mathrm{C}$ for $12 \mathrm{~h}$ inhibited this restorative function (Table 3 ), consistent with proteolytic degradation of p57 in ECP (data not shown). Restoration of hydrophobicity was specific to ECP because the heterologous proteins bovine serum albumin, hen egg albumin, and rainbow trout serum were unable to completely restore cell surface hydrophobicity (Table 3)

\section{DISCUSSION}

Cell surface hydrophobicity is an important bacterial property which facilitates phagocytic engulfment, as well as attachment to substrates (Finlay \& Falkow 1989). A number of investigators have documented the hydrophobic nature of Renibacterium salmoninarum by the salt aggregation assay, adherence to hydrocarbons, and binding to nitrocellulose filters (Daly \& Stevenson 1987, Bruno 1988, Bandin et al. 1989). $R$. salmoninarum isolates lacking a hydrophobic cell sur-
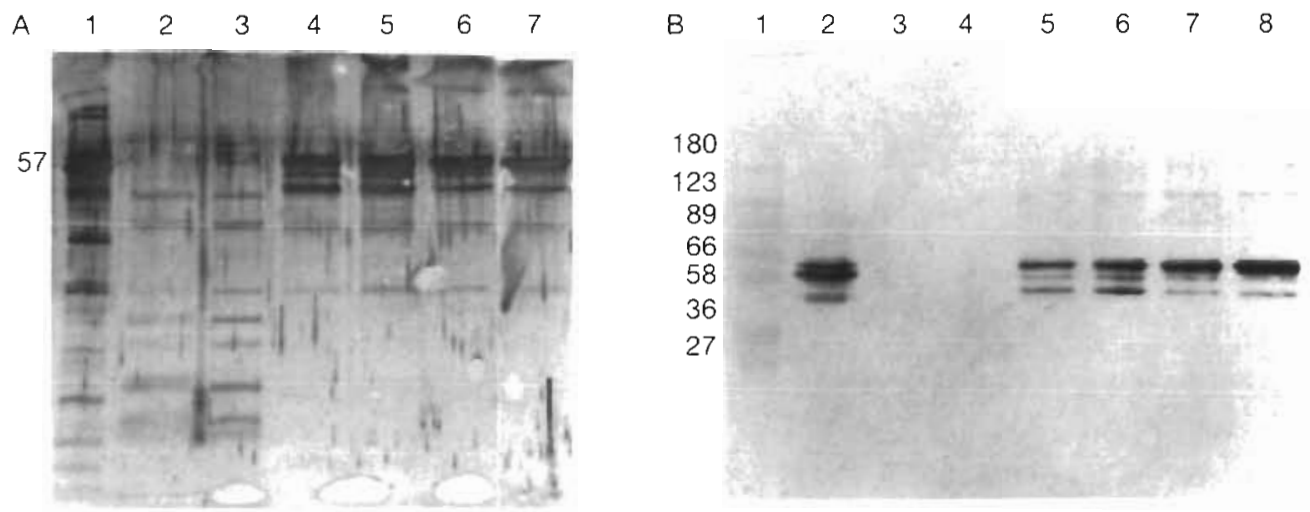

Fig. 2. Renibacterium salmoninarum. (A) Total protein stain and (B) western blot of cells incubated with or without PMSF at either 37 or $4^{\circ} \mathrm{C}$ for $12 \mathrm{~h}$. Lanes in (A) $R$. salmoninarum cells incubated at (A) $4{ }^{\circ} \mathrm{C}$, (2) $37^{\circ} \mathrm{C},(3) 37^{\circ} \mathrm{C}$ in $1 \%$ ethanol diluent, (4) $37^{\circ} \mathrm{C}$ in 2 $\mathrm{mM}$ PMSF, (5) $37^{\circ} \mathrm{C}$ in $5 \mathrm{mM}$ PMSF, (6) $37^{\circ} \mathrm{C}$ in $10 \mathrm{mM}$ PMSF, and (7) $37^{\circ} \mathrm{C}$ in $15 \mathrm{mM}$ PMSF. Lanes in (B): molecular weight markers (1) and $R$. salmoninarum cells incubated at (2) $4^{\circ} \mathrm{C}$, (3) $37^{\circ} \mathrm{C}$. (4) $37^{\circ} \mathrm{C}$ in $1 \%$ ethanol control ciluent, (5) $37^{\circ} \mathrm{C}$ in $2 \mathrm{mM} \mathrm{PMSF}$, (6) $37^{\circ} \mathrm{C}$ in $5 \mathrm{mM}$ PMSF, (7) $37^{\circ} \mathrm{C}$ in $10 \mathrm{mM}$ PMSF, and (8) $37^{\circ} \mathrm{C}$ in $15 \mathrm{mM}$ PMSF. Western blot was probed with anti-p57 monoclonal antibody 4D3 (Wiens \& Kaattari 1989) 
have been restricted to the ATCC 33209 and D6 isolates of $R$. salmoninarum.

At present the in vivo function of the secreted and cell-associated proteolytic activity is unclear, as the temperature of highest activity, $37^{\circ} \mathrm{C}$, is not physiologically relevant for either Renibacterium salmoninarum or the salmonid host. It is important to note that we have investigated a relatively restricted set of temperatures and that detailed characterization of the effects of temperature on proteolytic activity and hydrophobicity awaits further investigation. It is possible that a low level of activity is present at physiological temperatures (below $20^{\circ} \mathrm{C}$ ) and that this activity may function to modulate or regulate levels of p57 during infection. We hypothesize that proteolytic modulation of cell surface p57 may change adherence or invasive properties or may alter the antigenic characteristics recognized by the salmonid immune system. In support of this latter possibility we have recently demonstrated that immunization of chinook salmon with $37^{\circ} \mathrm{C}$ treated cells resulted in a 20 -fold increased antibody titer as compared to the titer of fish immunized with $R$. salmoninarum cells containing p57 (Wood \& Kaattari 1996). Clearly, further purification of serine protease activity and characterization of antigens unmasked or created during $37^{\circ} \mathrm{C}$ incubation are required for further elucidation of the in vivo significance of $\mathrm{p} 57$ modulation. In an accompanying report we describe the heat treatment of $R$. salmoninarum cells as a novel vaccine preparation and the incorporation of treated cells into a cellular vaccine in $\mathrm{pH}$ protected, entericcoated antigen microspheres (Piganelli et al. 1998).

Acknowledgements. This research was supported in part by Bonneville Power Administration award \#DE-PG7989BP95906, USDA CSRS grant \#92-34123-7665, and a Sigma Xi grant-in-aid of research awarded to G.D.W. The authors thank Drs J A. Leong, J. M. Christensen, J Heidel and D. Mattson for their critical review of this manuscript. We also thank Robin M. Braun for help with the salt aggregation assays

\section{LITERATURE CITED}

Austin B, Austin DA. (1987) Bacterial fish pathogens: diseases in farmed and wild fish. Ellis Norwood Limited, Chichester

Bandin I, Santos Y, Barja JL, Toranzo AE (1989) Influence of the growth conditions on the hydrophobicity of Renibacterium salmoninarum evaluated by different methods. FEMS Microbiol Lett 60:71-78

Bandin I, Santos Y, Barja JL, Magarinos B, Toranzo AE (1992) The detection of two antigenic groups among Renibacterium salmoninarum isolates. FEMS Microbiol Lett 94: $105-110$

Bandin I, Ellis AE, Barja JL, Secombs CJ (1993) Interaction between rainbow trout macrophages and Renibacterium salmoninarum in vitro. Fish Sheilfish Immunol 3:25-33
Barton TA, Bannister LA, Griffiths SG, Lynch WH (1997) Further characterization of Renibacterium salmoninarum extracellular products. Appl Environ Microbiol 63: $3770-3775$

Bruno DW (1986) Histopathology of bacterial kidney disease in laboratory infected rainbow trout, Salmo gairdneri (Richardson), and Atlantic salmon, Salmo salar L., with reference to naturally infected fish. J Fish Dis 9:523-537

Bruno DW (1988) The relationship between auto-agglutination, cell surface hydrophobicity and virulence of the fish pathogen Renibacterium salmoninarum. FEMS Microbiol Lett 51:135-140

Bruno DW (1990) Presence of a saline extractable protein associated with virulent strains of the fish pathogen Renibacterium salmoninarum. Bull Eur Assoc Fish Pathol 10: $8-10$

Daly JG, Stevenson RM (1987) Hydrophobic and haemagglutinating properties of Renibacterium salmoninarum. J Gen Microbiol 133:3575-3580

Daly JG, Stevenson RM (1990) Characterization of the Renibacterium salmoninarum haemagglutinin. J Gen Microbiol 136:949-953

Elliott DG, Pascho RJ, Bullock GL (1989) Developments in the control of bacterial kidney disease of salmonid fishes. Dis Aquat Org 6:201-215

Evelyn TPT (1977) An improved growth medium for the kidney disease bacterium and some notes on using the medium. Bull Off Int Epiz 78:511-513

Evenden AJ, Grayson TH, Gilpin ML, Munn CB (1993) Renibacterium salmoninarum and bacterial kidney diseasethe unfinished jigsaw. Annu Rev Fish Dis 3:88-104

Finlay BB, Falkow S (1989) Common themes in microbial pathogenicity. Microbiol Rev 53:210-230

Fredriksen A, Endresen C. Wergeland HI (1997) Immunosuppressive effect of a low molecular weight suface protein form Renibacterium salmoninarum on lymphocytes from Atlantic salmon (Salmo salar L.) Fish Shellfish Immunol 7:273-282

Fryer JL, Sanders JE (1981) Bacterial kidney disease of salmonid fish. Annu Rev Microbiol 35:273-298

Getchell RG. Rohovec JS, Fryer JL (1985) Comparison of Renibacterium salmoninarum isolates by antigenic analysis. Fish Pathol 20(2/3):149-159

Griffiths SG, Lynch WH (1991) Instability of the major soluble antigen produced by Renibacterium salmoninarum. J Fish Dis 14:55-66

Gutenberger SK, Duimstra RJ, Rohovec JR, Fryer JL (1997) Intracellular survival of Renibacterium salmoninarum in trout mononuclear phagocytes. Dis Aquat Org 28(2): 93-106

Lindahl M, Faris A, Wadstrom T, Hjerten S (1981) A new test based on 'salting out' to measure relative surface hydrophobicity of bacterial cells. Biochem Biophys Acta 677: $471-476$

Piganelli JD, Wiens GD, Zhang JA, Christensen JM, Kaattari SL (1998) Evaluation of a whole cell, p57- vaccine against Renibacterium salmoninarum. Dis Aquat Org 36:37-44

Rockey DD, Gilkey LL, Wiens GD, Kaattari SL (1991a) Monoclonal antibody-based analysis of the Renibacterium salmoninarum p57 protein in spawning chinook and coho salmon. J Aquat Animal Health 3:23-30

Rockey DD, Turaga PSD, Wiens GD, Cook BA, Kaattari SL (1991b) Serine protease of Renibacterium salmoninarum digests a major autologous extracellular and cell surface protein. Can J Microbiol 37:758-763

Toranzo AE, Barja JL (1993) Virulence factors of bacteria pathogenic for coldwater fish. Annu Rev Fish Dis 3:5-36 
Turaga PSD, Wiens GD, Kaattari SL (1987a) Analysis of Renibacterium salmoninarum antigen production in situ. Fish Pathol 22:209-214

Turaga PSD, Wiens G, Kaattari S (1987b) Bacterial kidney disease: the potential role of soluble protein antigen(s). J Fish Biol Suppl A 31:191-194

Wiens GD, Kaattari SL (1989) Monoclonal antibody analysis of common surface protein(s) of Renibacterium salmoni-

Editorial responsibility: Donald Evans,

Athens, Georgia, USA narum. Fish Pathol 24:1-7

Wiens GD, Kaattari SL (1991) Monoclonal antibody characterization of a leukoagglutinin produced by Renibacterium salmoninarum. Infect Immunol 59:631-637

Wood PA, Kaattari SL (1996) Enhanced immunogenicity of Renibacterium salmoninarum in chinook salmon after removal of the bacterial cell surface-associated $57 \mathrm{kDa}$ protein. Dis Aquat Org 25:71-79

Submitted: May 3, 1998; Accepted: September 11, 1998

Proofs received from author(s): March 10,1999 